\title{
The clinical prevalence of actinic cheilitis among community health agents from the regional $V$ subprefecture of Fortaleza
}

\author{
A prevalência da queilite actínica em agentes comunitários de saúde
}

Ana Carla Rocha Barreto'

\section{ABSTRACT}

\section{Objective}

The aim of this study was to evaluate clinically the prevalence of Actinic Cheilitis in community health agents from the Regional $V$ subprefecture of Fortaleza.

\section{Methods}

The sample consisted of 333 community health workers exposed to the sun on a daily basis. The community health agents were evaluated through a questionnaire (with information about the individual, their occupations and habits) and a clinical examination in the first stage of the study. In the second stage, the Actinic Cheilitis lesions were classified according to the degree of severity, monitored and treated as needed. Both stages were performed by just one examiner. The data were tabulated in an Excel spreadsheet and evaluated by means of the G-test.

\section{Results}

The results showed that the prevalence of Actinic Cheilitis was significantly associated with age, race / color and use of lip balm. A total of 101 (30.3\%) community health agents were found to have normal labial mucosa, 195 (58.5\%) had a mild alteration in Actinic Cheilitis, 34 (10.2\%) with moderate Actinic Cheilitis and in 3 (0.9\%) severe change was identified.

\section{Conclusion}

The study concluded that the prevalence of Actinic Cheilitis is high among the community health agents from the Regional $\mathrm{V}$ subprefecture of Fortaleza.

Indexing terms: Actinic cheilitis. Diagnosis. Treatment.

\section{RESUMO}

\section{Objetivo}

Avaliar clinicamente a prevalência da queilite actínica em agentes comunitários de saúde na Regional $\vee$ de Fortaleza.

\section{Métodos}

A amostra foi composta por 333 agentes comunitários de saúde. Os agentes comunitários de saúde, expostos diariamente ao sol, receberam esclarecimentos sobre a lesão, responderam um questionário (com informações pessoais, ocupacionais e habituais) na primeira etapa do estudo. Na segunda etapa do estudo, foram avaliados clinicamente, tiveram as lesões suspeitas fotografadas e classificadas quanto ao grau de severidade, acompanhadas e tratadas de acordo com a necessidade. As duas etapas foram realizadas por um, único, examinador. Os dados foram tabulados em planilha Excel e avaliados pelo teste $\mathrm{G}$.

\section{Resultados}

Os resultados mostraram, que a prevalência da queilite actínica foi significativamente associada à faixa etária, etnia/cor e uso de protetor labial. Foram encontrados 101 (30,3\%) agentes comunitários de saúde com mucosa labial normal, 195 (58,5\%) com alteração discreta de queilite actínica, $34(10,2 \%)$ portadores de queilite actínica, moderada e em $3(0,9 \%)$ identificou-se alteração intensa.

\section{Conclusão}

O estudo concluiu que a prevalência da queilite actínica, é alta entre os agentes comunitários de saúde da Regional $\vee$ de Fortaleza.

Termos de indexação: Queilite actínica. Diagnóstico. Tratamento.

\footnotetext{
${ }^{1}$ Faculdade São Leopoldo Mandic - Unidade Fortaleza. Rua Padre Valdevino, 1415, Aldeota, 60135-041, Fortaleza, CE, Brasil. Correspondência para / Correspondence to: ACR BARRETO. E-mail: <anacarlarochabarreto@hotmail.com>.
} 


\section{INTRODUCTION}

Actinic Cheilitis (AC) is a premalignant condition that results from frequent and prolonged exposure to sunlight ${ }^{1}$. It has a variety of nomenclatures, namely: Solar Cheilosis, Actinic Keratosis, Solar Keratosis, Actinic Cheilosis, Actinic Keratosis of the Lip, however AC is the term most commonly used in the literature ${ }^{2-3}$. AC may also transform into squamous cell carcinoma of the lip (SCCL) ${ }^{4}$.

Its transformation is a consequence of continuous, prolonged exposure to solar radiation ${ }^{5}$. Solar radiation is regarded as the most important etiological agent in $\mathrm{AC}^{4-7}$. Other important etiological factors of SCCL include tobacco and alcohol. The transformation occurs in approximately $10-20 \%$ of cases $^{8}$.

It has a predilection for the lower lip, fair-skinned individuals and males aged between 40 and 80, living in rural areas and workers with constant exposure to the $\operatorname{sun}^{4,6}$.

Its biological and physiopathological behavior is similar to that of actinic keratosis of the skin, manifesting itself in three ways, as white lesions in the form of nonulcerated plaque, erosions or ulcers on the lip or a mixture of white and ulcerated lesions ${ }^{9}$. The diagnosis of $A C$ is based on clinical and histological findings. Clinically, it has a slow development that can lead to atrophy of the vermillion on the lower lip, a darkening of the margin, or rough, squamous areas, developing in the more dried-up areas of the vermillion. It is characterized by erosion, edema and the formation of a crust ${ }^{10}$. In the beginning, the lips appear rough and dry, and afterwards perpendicular grooves or fissures appear at the vermillion border. In more advanced cases, the diffuse edema of the lip is more common as well as a loss at the vermillion border ${ }^{11}$.

Histologically, AC presents with atrophic stratified squamous epithelium with the production of keratin and various degrees of atypia. The underlying tissue shows a basophilic, acellular and amorphous alteration, known as actinic (solar) elastosis, presumably the result of an alteration in the collagen and elastic fibers induced by the ultraviolet light (UV) ${ }^{12}$.

According to information concerning work and leisure activities in external environments or high levels of exposure to the sun, without the correct protection, the patient should be instructed by the dentists to perform a self-examination and make use of sun protection.

Although oral cancer treatment has made good progress, it is necessary for an individual with $A C$ to be diagnosed early, so treatment must begin with a clinical examination and, depending on the severity, the $A C$ must be treated and monitored. The histological variables, with different degrees of keratinization, are also motives for early diagnosis and adequate treatment preventing lip carcinoma.

Therefore, given the risk of $A C$ evolving into a SCCL, this study proposes an evaluation of the prevalence of $\mathrm{AC}$ in the lay healthcare workers known as Community Health Agents $(\mathrm{CHAs})^{13}$. Suspected $A C$ lesions will be classified in terms of the degree of severity, treated and monitored as needed. The benefits for the CHAs will be the instruction, monitoring and treatment of the lesion by qualified professionals, the Dental Surgeons. CHAs presenting with severe $A C$ should be referred to the reference services.

\section{METHODS}

The research study was approved by the Research Ethics Committee at the São Leopoldo Mandic Faculty of Dentistry, under reference n. 2014/0378.

A clinical study was conducted into the prevalence of $A C$ in the CHAs in the city of Fortaleza. The sample size was $333 \mathrm{CHAs}$, chosen according to the Regional $\mathrm{V}$ subprefecture where they worked in the period between September 2014 and September 2015. In order to evaluate the presence of $A C$, an age range of 20 to 60 was applied with no restrictions as to gender and, to this end, a further important factor was involved, namely that those present had at least one year in the profession. Therefore, CHAs with less than one year in the profession, aged under 20 or over 60 , were excluded from the study.

\section{Stages of analysis}

\section{Part one}

Presentations were given to clarify the aims of the study. The individuals were then asked to complete a free and informed consent form. The interviewees answered a questionnaire in which they supplied their name, date of birth, sex, country of birth, ethnicity, whether or not they were smokers, drank alcohol or if they had used illicit drugs, how much time they were exposed to the sun and what was their daily exposure level. Next, a clinical examination was conducted to evaluate the presence of suspected AC lesions, including a classification of the lesions as to degree of severity. The clinical examination took place in a dental chair with focus and the required instrumentation, a wooden spatula. 


\section{Part two}

Individuals with suspected AC lesions were photographed and the classification was checked with regard to the degree of severity of the lesion, based on the classification proposed by the WHO (2005):

a) Mild AC: rough, dry lips;

b) Moderate AC: grooves or cracks perpendicular to the vermillion border (demarcation between the lip and adjacent skin);

c) Severe AC: diffuse edema of the lip and effacement of the subcutaneous mycosis border ${ }^{11}$.

All the clinical examinations were conducted by the researcher himself, and were noted on the clinical record together with information about family members (up to second-degree relatives who had had some form of cancer). After the anamnesis and clinical evaluation had been completed, the patients were informed that they would need to return for additional examinations, depending upon the degree of alteration presented, and those with a moderate or severe AC diagnosis were referred for biopsy and subsequently the required treatment and given appropriate directions concerning prevention and specific protection.

\section{RESULTS}

Of the total of 562 CHAs from the Regional $V$ subprefecture of Fortaleza, who had suffered exposure to the sun, 333 were examined, of which $83.8 \%$ were female and $16.2 \%$ were male. Of the population examined, $33.6 \%$ were white, $55.6 \%$ were brown and $10.8 \%$ were black.

Of the total of participants clinically examined (333), 101 (30.3\% had normal labial mucosa, 195 (58.6\%) had a mild degree of AC, $34(10.2 \%)$ were identified as having moderate $A C$, while $3(0.9 \%)$ were identified as having a severe degree of the condition.

As far as gender is concerned, the prevalence of labial alteration through AC did not demonstrate a significant association with gender $(p=0.602)$. As for the age range, which was stratified using the median age of the participants as the criterion, it was observed that the prevalence of $A C$ and the degree of severity was significantly associated with the age range $(p=0.032)$. A significantly larger proportion of CHAs aged 40 or over had a moderate alteration in the labial mucosa on account of AC. Severe AC was not observed among the participants aged under 40. As far as ethnicity/color is concerned, the prevalence of AC among whites and browns was mild, $63.4 \%$ and $64.3 \%$ respectively, while this figure was significantly higher than in blacks, of whom $13.9 \%$ presented with a mild degree of $A C$. As for moderate levels of $A C$, prevalence was significantly higher among whites.

Table 1. Absolute ( $n$ ) and relative (\%) frequency distribution of the degree of change in the labial mucosa due to AC, by sex, age range and ethnicity/ color.

\begin{tabular}{|c|c|c|c|c|c|c|}
\hline \multirow[b]{2}{*}{$\begin{array}{l}\text { BHCU } \\
\text { Sex }\end{array}$} & \multicolumn{6}{|c|}{ Degree of change in labial mucosa due to actinic cheilitis } \\
\hline & $\begin{array}{c}\text { Normal } \\
\text { n (\%) }\end{array}$ & $\begin{array}{l}\text { Slight } \\
\text { n (\%) }\end{array}$ & $\begin{array}{c}\text { Moderate } \\
\text { n (\%) }\end{array}$ & $\begin{array}{l}\text { Intense } \\
\mathrm{n}(\%)\end{array}$ & $\begin{array}{l}\text { Total } \\
\text { n (\%) }\end{array}$ & p value* \\
\hline Female & $82(29.4 \%)^{¥}$ & $166(59.5 \%)^{*}$ & $28(10.0 \%)^{*}$ & $3(1.1 \%)^{*}$ & $279(83.8 \%)^{€}$ & \multirow{2}{*}{0.6207} \\
\hline Total & $101(30.3 \%)^{€}$ & $195(58.6 \%)^{€}$ & $34(10.2 \%)^{€}$ & $3(0.9 \%)^{€}$ & $333(100 \%)$ & \\
\hline Up to 39 & $57(34.1 \%)^{¥}$ & $98(58.7 \%)^{¥}$ & $12(7.2 \%)^{¥}$ & $0(0.0 \%)^{*}$ & $167(50.2 \%)^{€}$ & \multirow[t]{3}{*}{0.032} \\
\hline 40 or over & $44(26.5 \%)^{¥}$ & $97(58.4 \%)^{*}$ & $22(13.3 \%)^{*}$ & $3(1.8 \%)^{*}$ & $166(49.8 \%)^{€}$ & \\
\hline Total & $101(30.3 \%)^{€}$ & $195(58.6 \%)^{€}$ & $34(10.2 \%)^{€}$ & $3(0.9 \%)^{€}$ & 333 (100\%) & \\
\hline \multicolumn{7}{|c|}{ Ethnicity/Color } \\
\hline Total & $101(30.3 \%)^{€}$ & $195(58.6 \%)^{€}$ & $34(10.2 \%)^{€}$ & $3(0.9 \%)^{€}$ & $333(100 \%)$ & $<0.001$ \\
\hline
\end{tabular}

Note: ${ }^{*}$ Percentage of each gender, age range and ethnicity/color. ${ }^{\epsilon}$ Percentage of total sample (333). * G-test. 
The prevalence of AC was not associated with length of exposure $(p=0.746)$. Taking into account the stratification performed using the median, exposure for up to 6 years, or for 7 years or more, did not have an influence on the prevalence of AC. Moreover, the habits of drinking alcohol and smoking (currently, or in the past), were not significantly associated with $A C(p=0.926)$. The G-test demonstrated that the use of lip balm significantly influenced the degree of $A C(p<0.001)$. When the use of lip balm was reported, $47.5 \%$ of the CHAs presented with a mild level (44.1\%) or moderate level (3.4\%) of AC. On the other hand, when the lip balm was only "sometimes" used, $68.8 \%$ of the CHAs had AC, of which $59.4 \%$ were classified as mild and $9.4 \%$ moderate.

Accordingly, as can be observed in table 2, the proportion of CHAs free of $\mathrm{AC}$ gradually reduced as the reported use of lip balm was more frequent (52.5\%), sporadic $(31.3 \%)$ and in situations where protection was not employed (22.5\%).

Table 2. Absolute (n) and relative (\%) frequency distribution of degree of change in the labial mucosa due to actinic cheilitis, by length of exposure, habit and use of lip balm.

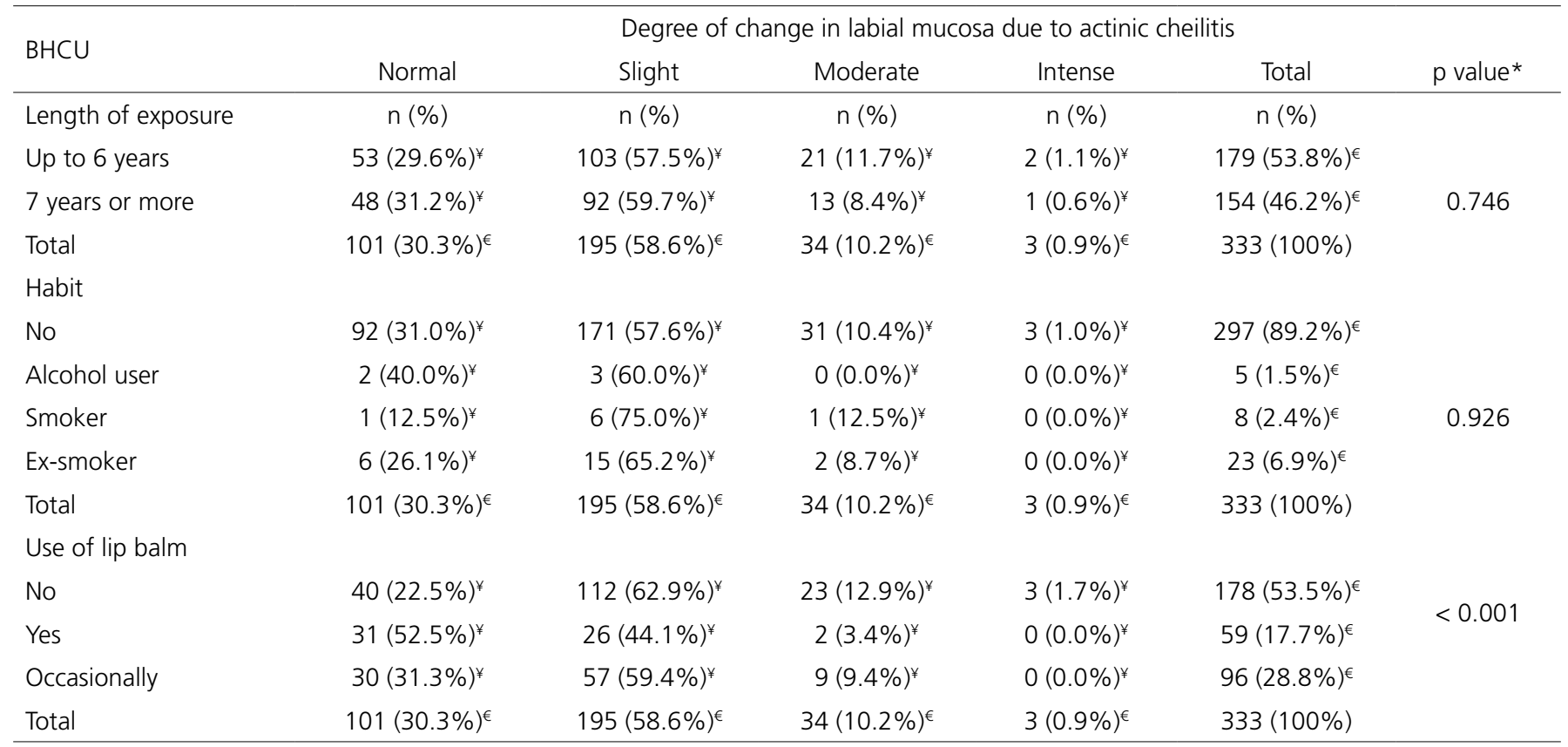

Note: ${ }^{*}$ Percentage of length of exposure, habit and use of lip balm. ${ }^{€}$ Percentage of total sample (333). * G-test.

\section{DISCUSSION}

AC is a potentially malignant lesion that affects the lip when there is prolonged exposure to the sun ${ }^{9,14-}$ ${ }^{16}$. Early diagnosis is extremely important in preventing malignant transformation ${ }^{16}$. According to Barreiros et al. ${ }^{17}$, few studies have demonstrated the prevalence of this pathology's malignant transformation. This is in contrast to Calcaianu et al. ${ }^{16}$, who assessed malignant transformation of $A C$ at $16.9 \%$.

In the present study of 333 participants (CHA), gender did not present any statistical difference, similar to Barreiros et al. ${ }^{17}$ who did not find any differences between the sexes in $A C$ sufferers. The literature reveals that this disease afflicts the male patient profile, in agreement with the studies of Martins et al. ${ }^{14}$, Miranda et al. ${ }^{18}$; Pilati ${ }^{19}$, Cintra et al. ${ }^{20}$. However, this lesion most commonly affects males because men routinely undertake open air activities for long periods of time. This is demonstrated by Lemos et al. ${ }^{21}$ and Martins et al. ${ }^{14}$.

This study revealed that exposure to the sun of between six and seven years or more did not have any influence on the prevalence of AC. In Brazil, Silva et al. ${ }^{22}$ conducted a study of fishermen on the island of Santa Catarina, in which 111 fishermen were examined and 48 $(43.2 \%)$ were diagnosed with $A C$, confirming that exposure to the sun's rays for over six hours daily, agreeing with the results of our study, namely the longer the patients are exposed, the greater the prevalence of $A C$, and without protection the prevalence of $A C$ increases significantly, as 
shown by Corso et al. ${ }^{23}$ who assessed 2,432 patient files from the Stomatology Clinic at the Pontifical Catholic University of Paraná (PUCPR) and found 11 cases of AC, corresponding to $0.45 \%$ of the evaluated population. This study reported that the patients were constantly exposed to sunlight in $81.8 \%$ of the cases. Junqueira et al., 2011 proved that exposure to sunlight is the greatest risk factor for $A C$, the proof being that among the 202 farm workers, the prevalence of $A C$ was $39.6 \%$. According to the studies of Domaneschi et al. ${ }^{13}$ and Tommasi ${ }^{24}$, this lesion is a chronic process requiring years of exposure to the sun.

In terms of drinking and smoking (currently, or in the past), these did not contribute to the emergence of $A C$ in the participants in the present study, agreeing with the results of Junqueira et al. ${ }^{4}$ but differing from Barreiros et al. ${ }^{17}$, Corso et al. ${ }^{23}$ and Markopoulos et al. ${ }^{7}$.

With regard to age, the prevalence of $A C$ among the individuals in the study was statistically significant. Up to 39 years of age, the severe form of AC was not observed, while in those aged 40 and over a moderate alteration in the labial mucosa, caused by AC, could be observed. Proportionally, this was in agreement with the results obtained by Cintra et al. ${ }^{20}$ which noted a prevalence of $68.3 \%$ in individuals between the ages of 20 and 44 . It should be remembered that between these ages is the peak period of activity for rural workers. The study by Corso et al. ${ }^{23}$ also reported a higher frequency of $A C$ in the 50 year-old age group, mainly because these patients, in $81 \%$ of cases, were constantly exposed to solar radiation. Similarly, no relationship was observed between the greater prevalence of $A C$ and age group in the population of farm workers in the Campinas region, evaluated by Junqueira et al. ${ }^{4}$. The studies of Barreiros et al. ${ }^{17}$, Junqueira et al. ${ }^{4}$ and Corso et al. ${ }^{23}$ disagree in terms of the age groups, however all of them agree that ultraviolet radiation needs to be chronic and in greater intensity as the years go by. It should be stressed that the patients' occupations/length of exposure and age could be associated with the etiology of $A C$.

This study showed that AC is significantly linked to ethnicity/color, presenting the following data: $63.4 \%$ in mild alterations, in whites, and $64.3 \%$ in browns. As for black individuals, the figure was $13.9 \%$ with mild $A C$. In the case of Miranda et al. ${ }^{18}$ and Arnaud et al. ${ }^{25}$, the prevalence of $A C$ in whites is statistically significant when compared to non-whites. The results obtained by Barreiros et al. ${ }^{17}$ showed that $100 \%$ of sufferers were Caucasian. This is in contrast to what was found in the study by Abreu et al. ${ }^{26}$ with 31 patients, of whom 26 (83.8\%) were white, $4(12.9 \%)$ were brown and only $1(3.2 \%)$ was black. Therefore, in the literature, there is a predominance of $A C$ in fair-skinned patients.

In the present study, the use of lip balm was extremely influential, it being reported that $47.5 \%$ of participants used lip balm, $44.1 \%$ presented with mild AC and $3.4 \%$ moderate AC. Of those study participants that used lip balm only sometimes, 59.4\% had mild AC and $9.4 \%$ moderate AC. When the participants in this study did not use lip balm, 77.5\% had mild AC, 62.9\% moderate $A C$ and $1.7 \%$ severe $A C$. Domaneschi et al. ${ }^{13}$ concluded, in their studies, that the prescription of sun protection measures, such as wide-brimmed hats and the systematic application of sunblock on the skin and lips, should be a part of the treatment and monitoring procedure for patients. Many studies ${ }^{27-29}$ reported on the etiology of $A C$ but very few preventive campaigns were conducted by professionals in the area. The present study noted that few CHAs use sun protection on the lips, a major ally in the prevention of AC. The results presented by Miranda ${ }^{30}$ found a prevalence of AC of $9.16 \%$ among rural workers, but only in passing mention the need for prevention. Pilati ${ }^{19}$ in her study, showed that the majority of patients presenting with $A C$ have occupations that involve exposure to sunlight, but at no point does she emphasize the need for these patients to use lip balm.

The prevalence results found in this study, as well as the variables related to the clinical manifestation of $A C$ in CHAs, proved that it was necessary to use lip balm, particularly workers that suffer constant exposure to sunlight. Professionals in the area of dentistry have a responsibility to educate, monitor and treat $A C$ in order ultimately to reduce the lesion's clinical manifestation, as it is potentially malignant.

\section{CONCLUSION}

The prevalence of $A C$ in the studied population was $67.9 \%$, considered high, the mild alteration being the most common, mainly among individuals that do not use lip balm.

\section{Collaborators}

The author participated in all stages of the preparation of the manuscript. 


\section{REFERENCES}

1. Araújo CP, Vidal MTA, Gurgel CAS, Ramos EAG, Junior $A$ de $A$ B, Ramalho LMP, et al. Queilite actínica: um estudo de 35 casos com destaque para os aspectos morfológicos. Rev Pós Grad. 2012;19(1):21-7.

2. Main $\mathrm{JH}$, Pavone $\mathrm{H}$. Actinics cheilitis and carcinoma of the lip. J Can Dent Assoc. 1994;60:113-6.

3. Kaugars GE, Pillion T, Svirsky JA, Page DG, Burns JC, Abbey LM. Actinis Cheilitis a revies of 152 cases. Oral Surg Oral Med Oral Pathol Oral Radiol Endod. 1999;88:181-186.

4. Junqueira JLC, Bonecker M, Furuse C, Morais PC, Flório FM, Cury PR, et al. Chronic actinic cheilitis. J Am Med Assoc. 1923;81(14):1183-6.

5. Rojas IG, Martinez A, Pineda A, Spencer ML, Jimenez M, Rudolph Ml. Increased mast cell density and protease content in actinis cheilitis. J Oral Pathol Med. 2004;33:567-73.

6. Acquavella J, Olsen G, Cole P. Cancer among farmers: a metaanalysis. Ann Epidemiol. 1998;8:64-74.

7. Markopoulos A, Albanidou-Farmaki E, Kayavis I. Actinic cheilitis clinical and pathology characteristics in 65 cases. Oral Dis. 2004 July; 10(4):212-6

8. Santos JN, Sousa SO, Nunes FD, Araujo VC. Altered cytokeratin expression. In actinic cheilitis. J Cutan Pathol. 2003;30:1-5.

9. Véo PCR, Farias RE, Stehling RSS, Urbano E S. Tratamento cirúrgico da queilose actínica. RGO, Rev Gauch Odontol. 2010;58(3):93-7.

10. Reichart, P.A.; Philipsen, H.P. Lábios: atlas colorido de Odontologia. Porto Alegre:Artes Médicas Sul; 2000.

11. Lundeen RC, Langlais RP, Terezhalmy GT. Sunscreen protection fot lip mucosa: a review and update. J Am Dent Assoc. 1985;111:617-621.

12. Neville BW, Damm DD, Allen CM, Bouquot JE. Patologia oral e maxilofacial. $2^{a}$ ed. Rio de Janeiro: Elsevier; 2004. p. 340-1.

13. Domaneschi C, Santos SG, Navarro CM, Massucato EMS. Queilite actínica, associação entre radiação actínica e trauma. RGO, Rev Gauch Odontol. 2003;51(2):101-4.

14. Martins MD, Marques LO, Martins MAT, Bussadori JK, Fernandes KPS. Queilite actínica: relato de caso clínico. Consc Saúde. 2007;1(6):105-10.

15. Araujo CP, Barros AC, Lima AAS de, Azevedo RA, Ramalho L, Santos JN. Estudo histológico e histoquimico da elastose solar em lesões de queilite actínica. Rev Ci Méd Biol. 2007;6(2):152-9.

16. Calcaianu N, Popescu SA, Diveica D, Lascar I. Surgical attitude in premalignant lesions and malignant tumors of the lower lip. J Med Life. 2015;8(1):109-111.
17. Barreiros ALC, Nascimento GG, Junqueira JLC, Araújo VC, Furuse C. Actinic cheilitis: epidemiological study in a riverine population of northern Brazil. J Res Dent. 2014;2(3):262-268.

18. Miranda AM, Ferrari TM, Calandro TLL. Queilite actínica: aspectos clínicos e prevalência encontrados em uma população rural no interior do Brasil. Rev Saúde Pesq. 2011;4(1):67-72.

19. Pilati SFM. Estudo de características clínicas e histopatológicas da queilite actínica e carcinoma epidermoide de lábio [dissertação]. Santa Catarina: Universidade Federal de Santa Catarina; 2012.

20. Cintra JS, Torres SCM, Silva MBF, Junior LRM, Filho JP da $S$ Junqueira JLC. Queilite actínica: estudo epidemiológico entre trabalhadores rurais do municipio de Piracaia-SP. Rev Assoc Paul Cir Dent. 2013;67(2):118-21.

21. Lemos MA dos S, Maciel TAO, Matos FR de, Amorim AG, Galvão HC. Queilite actínica: estudo clinicopatológico de 46 casos. UNOPAR Cient Cien Biol Saude. 2009;11(3):9-12.

22. Silva FD, Daniel F, Grando LJ, Calvo MC, Rath IBS, Fabro SML. Estudo da prevalência de alterações labiais em pescadores da Ilha de Santa Catarina. Rev Odonto Ciência. 2006 janmar;21(51):37-42.

23. Corso FM, Wild C, Gouveia L de O, Ribas M de O. Queilite Actínica: prevalência na clínica estomatológica da PUCPRCuritiba- Brazil. Clin Pesq Odontol. 2006;2(4):277-281.

24. Tommasi AF. Diagnóstico em patologia bucal. São Paulo: Pancast; 2002. p. 377

25. Arnaud RR, Soares MSM, Paiva MAF de, Figueiredo CRLV, Santos MGC dos, Lira CC. Queilite Actínica: avaliação histopatológica de 44 casos. Rev Odontol UNESP. 2014 Nov-dec;43(6):384-389.

26. Abreu MPMM, Silva OMP, Pimentel DRM, Hirata CHW, Weckx LLM, Alchome MMA, et al. Actinic cheilitis adjacente to squamous carcinoma of the lip as na indicator of prognosis. Rev Bras Otorrinolaringol. 2006 Nov-dez;72(6):12-24.

27. Cavalcante ASR, Anbinder AL, Carvalho YR. Actinic Cheilitis: Clinical and Histological Features. Am Assoc Oral Maxillofac Surg. 2008;66:498-503.

28. Martins-Filho PRS, Silva LCF da, Piva MR. The prevalence of actinic cheilitis in farmers in a semi-arid northeastern region of Brazil. Int J Dermatol. 2011;50:1109-1114.

29. Lucena EE de S, Silveira EJD da, Lima KC. Prevalence and factors associated to actinic cheilitis in beach workers. Oral Dis. 2012;18:575-579.

30. Miranda AM de O. Prevalência da Queilite Actínica em uma população brasileira [dissertação]. Rio de Janeiro: Unigranrio; 2009. 